\title{
State-Dependent AMPA Receptor Trafficking in the Mammalian Retina
}

\author{
Yingqiu Xia, ${ }^{1}$ Reed C. Carroll, ${ }^{1 *}$ and Scott Nawy ${ }^{1,2 *}$ \\ Departments of ${ }^{1}$ Neuroscience and ${ }^{2}$ Ophthalmology and Visual Sciences, Albert Einstein College of Medicine, The Rose F. Kennedy Center, Bronx, New \\ York 10461
}

The rapid cycling of AMPA receptors (AMPARs) at the membrane maintains synaptic transmission at a number of CNS synapses and may play a role in several forms of synaptic plasticity. It is unclear, however, how prevalent the trafficking of AMPARs is in the CNS, particularly at synapses not known to exhibit activity-dependent plasticity. Because trafficking is regulated by basal synaptic activity, a question also remains as to how receptor trafficking is modulated at synapses subject to different patterns of synaptic activation. We have investigated whether trafficking of AMPARs occurs in retinal neurons, which are subject to tonic glutamate release. We find two distinct states of AMPAR trafficking in ON ganglion cells. Light adaptation serves to stabilize AMPARs in a noncycling mode. However, dark adaptation for as little as $8 \mathrm{~h}$ triggers a switch to a second state of trafficking characterized by rapid cycling. We provide evidence that the activation of AMPARs is critical for switching between cycling and noncycling states. The induction of cycling further appears to be modulated by changes in the function of glutamate receptor 2/3-interacting proteins. Our results suggest that there is a strong link between synaptic activity and AMPAR trafficking in retinal neurons. These results further suggest the existence of a previously unknown form of activity-dependent plasticity in the retina that may be regulated in the course of a normal light/dark cycle.

Key words: retina; AMPA receptor; trafficking; PICK1; GRIP; activity; ganglion cell; light; SVKI; dynamin; mouse

\section{Introduction}

AMPA receptors (AMPARs) are the primary mediators of excitatory synaptic transmission in the CNS, and tight regulation of their synaptic levels is critical for proper neuronal development and function (Malinow and Malenka, 2002). Basal AMPAR expression is controlled at a number of synapses not only by the metabolic turnover of receptors, but also by rapid receptor cycling, characterized by a turnover rate in the tens of minutes (Luscher et al., 1999; Ehlers, 2000; Lin et al., 2000).

The role of receptor cycling is uncertain but may serve as a platform for the expression of synaptic plasticity (Sheng and Lee, 2001; Malinow and Malenka, 2002; Bredt and Nicoll, 2003). In addition to receptor cycling, the most highly studied form of trafficking involves the activity-dependent removal and delivery of receptors to the synapse, which have been identified as the mechanisms behind several forms of long-term synaptic plasticity (Carroll et al., 2001; Malinow and Malenka, 2002). By altering the cycling rate or relative stabilization of AMPARs in intracellular or surface pools, activity could lead to rapid changes in the surface levels or subunit composition of AMPARs (Liu and CullCandy, 2000, 2002, 2005; Turrigiano, 2000; Sheng and Lee, 2001; Lee et al., 2004). A link between receptor cycling and activitydependent plasticity is supported by the observations that deple-

\footnotetext{
Received 0ct. 6, 2005; revised April 4, 2006; accepted April 5, 2006.

This work was supported by National Institutes of Health Grants NS049661 (R.C.C.) and EY10254 (S.N.). *R.C.C. and S.N. contributed equally to this work.

Correspondence should be addressed to Scott Nawy at the above address. E-mail: nawy@aecom.yu.edu. D0I:10.1523/JNEUROSCI.0169-06.2006

Copyright $\odot 2006$ Society for Neuroscience $\quad$ 0270-6474/06/265028-09\$15.00/0
}

tion of cycling AMPARs occludes CA1 hippocampal long-term depression (LTD) (Luscher et al., 1999) and that similar molecular mechanisms contribute to regulated AMPAR endocytosis and the recycling of AMPARs (Gardner et al., 2005; Lu and Ziff, 2005).

The cycling of AMPARs has been observed in highly plastic brain regions including the hippocampus and cortex (Malinow and Malenka, 2002; Lu et al., 2003; Takahashi et al., 2003; Tomita et al., 2004). However, the question remains as to whether rapid receptor turnover plays a role in a wider range of functionally disparate synapses and how activity, the levels of which are greatly varied at different synapses, can locally and specifically contribute to the regulation of AMPAR levels. A particular challenge for maintaining synaptic stability in response to activity lies in the retina, where neurons release glutamate continuously. The possibility of receptor trafficking in the retina is supported by the observed colocalization in rat and monkey retina of AMPAR subunits glutamate receptor $2 / 3$ (GluR2/3) with glutamate receptorinteracting protein/AMPAR-binding protein (GRIP/ABP) (Ghosh et al., 2001; Gabriel et al., 2002), regulatory proteins that interact with the $\mathrm{C}$ terminus of GluR2/3 subunits and modulate regulated receptor trafficking (Henley, 2003).

In the present study, we provide evidence for two distinct states of basal AMPAR trafficking. Specifically, we show that light-driven activity maintains AMPARs in a noncycling state, whereas the reduction of activity in the ON pathway with lightdeprivation preferentially induces $\mathrm{ON}$ ganglion cells to rapidly cycle AMPARs at the membrane surface. Our results suggest a strong link between synaptic activity and AMPAR trafficking in retina. Furthermore, the conditional cycling of AMPARs repre- 
sents a previously unknown form of activity-dependent plasticity in the retina that can be triggered by changes in light during the day/night cycle.

\section{Materials and Methods}

Whole-mount and retinal slice preparation and recording. Mice (C57BL/6) or Sprague Dawley rats (Charles River, Cambridge, MA) were anesthetized with halothane (Sigma, St. Louis, MO) and killed by cervical dislocation. A piece of retina $\sim 2 \times 2 \mathrm{~mm}^{2}$ was dissected from the area close to the optic nerve, peeled off from the sclera and pigment epithelium, in a dish containing Ames media (Sigma) bubbled with $95 \% \mathrm{O}_{2}$ and $5 \% \mathrm{CO}_{2}$. The retina was transferred to the recording chamber and placed flat, ganglion cell layer up, over a $5 \times 5 \mathrm{~mm}^{2}$ cellulose acetate/nitrate membrane filter (Millipore, Bedford, MA) with a hole in the center to allow light to pass through. The filter paper was attached with vacuum grease to the chamber. Retinas were bathed in Ames media at a flow rate of 3-5 $\mathrm{ml} / \mathrm{min}$ at room temperature. Access to ganglion cells was achieved by severing the Müller cell end feet with a pipette mounted on a second manipulator.

For measurements of light responses, mice were dark adapted for at least $1 \mathrm{~h}$ before the experiment, and retinas were dissected in intrared light. Ganglion cells were viewed through a $40 \times$ objective under infrared illumination with a CCD camera attached to a Nikon (Tokyo, Japan) Eclipse E600FN microscope. Light stimulation was provided by a $20 \mathrm{~W}$ halogen lamp focused through the $40 \times$ objective via a camera port equipped with a diaphragm to control the diameter of light spots. An interference filter (peak transmittance at $500 \mathrm{~nm}$ ) and neutral density filters were inserted in the light path to control the intensity and wavelength of light stimulation, and a shutter (Uniblitz, Rochester, NY) was used to control the duration of the stimulation. The intensity of the unattenuated light stimulus was measured to be $2.3 \times 10^{8}$ photons $\cdot \mu \mathrm{m}^{-1} \cdot \mathrm{s}^{-1}$ at $500 \mathrm{~nm}$. AMPA $(100 \mu \mathrm{M})$ was applied from a second pipette using positive pressure (2-4 psi) for 50-200 $\mathrm{ms}$ with the use of a computer-controlled solenoid valve (Picospritzer; General Valve, Fairfield, NJ). In several experiments, we recorded from amacrine cells using retinal slices from Sprague Dawley rats prepared essentially as described previously for salamander (Walters et al., 1998; Nawy, 1999).

Recording pipettes were pulled from borosilicate glass (World Precision Instruments, Sarasota, FL) by a two-stage vertical puller (Narishige, Tokyo, Japan) and filled with a $\mathrm{K}^{+}$gluconate-based solution (125 mM) that also contained $10 \mathrm{~mm}$ EGTA, $10 \mathrm{~mm}$ HEPES, $4 \mathrm{~mm}$ ATP, and $1 \mathrm{~mm}$ GTP, pH 7.4 by KOH. The osmolarity was 290 mOsm for recording in whole-mount retina and $310 \mathrm{mOsm}$ for cultured cell recordings. Pipette resistances were typically 3.5-5 M $\Omega$. Unless specified, cells were held at $\mathrm{E}_{\mathrm{Cl}-}$, calculated to be $-65 \mathrm{mV}$. Holding potentials were corrected for a $10 \mathrm{mV}$ junction potential, but series resistance, typically measuring 15-20 M $\Omega$, was not compensated for. Recordings were obtained with an Axopatch 200B using Axograph acquisition software and digitized with a Digidata 1322A interface (Molecular Devices, Union City, CA). Analysis was performed with Axograph and Kaleidagraph (Synergy Software, Reading, PA). Statistical significance of $p<0.05$ is indicated by ${ }^{*}$ and $p<$ 0.01 is indicated by ${ }^{* *}$.

Cell cultures and retina explants. Retinas were removed from newborn Long-Evans hooded or Sprague Dawley rats after cryoanesthesia and were incubated for $45 \mathrm{~min}$ at $37^{\circ} \mathrm{C}$ in DMEM with HEPES (Mediatech, Washington, DC), supplemented with $6 \mathrm{U} / \mathrm{ml}$ papain (Worthington, Freehold, NJ) and $0.2 \mathrm{mg} / \mathrm{ml}$ cysteine. Papain was then inactivated by replacing the enzyme solution with complete medium composed of DMEM, 5 mM HEPES, $0.1 \%$ Mito $^{+}$serum extender (Collaborative Research, Bedford, MA), 5\% heat-inactivated fetal calf serum, and $0.75 \%$ penicillin-streptomycin-glutamine mix (Invitrogen, San Diego, CA). The osmolarity was adjusted to $300 \mathrm{mOsm}$ by addition of distilled water. Retinas were triturated through a fire-polished Pasteur pipette, plated onto glass coverslips pretreated with poly-D-lysine $(0.1 \mathrm{mg} / \mathrm{ml})$, and maintained in complete medium supplemented with $15 \mathrm{~mm} \mathrm{KCl}$. At $72 \mathrm{~h}$ after plating, cells were treated with the antimitotics 5-fluoro-2deoxyuridine $(0.01 \mathrm{mg} / \mathrm{ml})$ and uridine $(0.026 \mathrm{mg} / \mathrm{ml})$ for $24 \mathrm{~h}$. Subsequently, every second day, $50 \%$ of the culture medium was exchanged for fresh medium. Cells were used for recording or immunohistochemistry at $8-21 \mathrm{~d}$ in vitro (DIV). For recording, the bath solution contained the following (in mM): $147 \mathrm{NaCl}, 2 \mathrm{KCl}, 2 \mathrm{CaCl}_{2}, 1.5 \mathrm{MgCl}_{2}$, and 10 HEPES, $\mathrm{pH} 7.4$.

For retinal-hippocampal cocultures, retinal cells were initially prepared as above. On the second day, $10 \mu \mathrm{M}$ CM-DiI (Invitrogen) was added to the culture medium for $24 \mathrm{~h}$ and washed out thoroughly before seeding with hippocampal cells from postnatal day 0 Sprague Dawley rats. Hippocampi were removed, and the dentate gyri were dissected out. Cells were dissociated in papain followed by trituration. Forty-eight hours after the seeding with hippocampal cells, cultures were maintained as described above.

Explants were made from C57BL/6 mice aged 3-6 weeks. Retinas were isolated and cut into pieces of $2 \times 2 \mathrm{~mm}$ in DMEM with HEPES (Mediatech). They were then transferred onto filter paper equipped with a hole in the center and attached to coverslips (Fisher Scientific, Pittsburgh, PA) with vacuum grease. The retina was submerged with Neurobasal media (Invitrogen) supplemented with $2 \%$ of B27, $0.75 \%$ penicillin-streptomycin-glutamine mix (Invitrogen) and $7.5 \mathrm{mg} / \mathrm{ml}$ glucose in culture dishes (Becton Dickinson Labware, Franklin Lakes, NJ). After overnight incubation at $37^{\circ} \mathrm{C}(16-20 \mathrm{~h})$, explants were transferred back to the recording chamber and perfused with Ames media for recording.

Immunocytochemistry. For GABA and Thyl.1 double staining, live cells were incubated with $10 \mu \mathrm{g} / \mathrm{ml}$ of a Thy 1.1 antibody (Chemicon, Temecula, CA) for $30 \mathrm{~min}$ at $37^{\circ} \mathrm{C}$ followed by several washes. After fixation with $4 \%$ paraformaldehyde in PBS for $15 \mathrm{~min}$, cells were then permeabilized with $0.1 \%$ Triton X-100 and $2 \%$ BSA in PBS and treated with a rabbit polyclonal antibody for GABA for $1 \mathrm{~h}$. FITC-conjugated donkey anti-rabbit and cyanine 3 (Cy3) donkey anti-mouse secondary antibodies (Jackson ImmunoResearch, West Grove, PA) were applied for $45 \mathrm{~min}$ at room temperature. Images from both fluorescent channels were acquired from a single focal plane. For protein interacting with $\mathrm{C}$ kinase (PICK1) labeling, permeabilized cells were incubated with antiPICK1 antibody (Affinity BioReagents, Golden, CO) for $1 \mathrm{~h}$ followed by detection with Cy3 donkey anti-mouse antibody. Slips were mounted in Vectashield (Vector Laboratories, Burlingame, CA).

For surface staining of GluR2-containing receptors, an antibody recognizing the extracellular $\mathrm{N}$ terminus of GluR2 subunit $(7.5 \mu \mathrm{g} / \mathrm{ml}$; Chemicon) was applied to live cells for $30 \mathrm{~min}$ at $37^{\circ} \mathrm{C}$ in complete medium. Cells were then fixed at indicated times with $4 \%$ paraformaldehyde in PBS for 10 min. After TBS wash, cells were blocked with $2 \%$ BSC in TBS and incubated with donkey anti-mouse Cy3 (5 $\mu \mathrm{g} / \mathrm{ml}$; Jackson ImmunoResearch) for $45 \mathrm{~min}$. After several washes, slips were mounted in Vectashield. Clusters of AMPARs were identified using a Nikon $60 \times$ objective and standard fluorescence and $\mathrm{Cy} 3$ filter sets (Omega, Brattleboro, VT). Fluorescent images of microscopic randomly chosen fields containing labeled neurons were acquired using a cooled CCD camera (Hamamatsu, Bridgewater, NJ). Images were analyzed using MetaMorph software (Molecular Devices). Images were background subtracted and thresholded to include only signals at least twofold greater than the diffuse labeling in dendritic shafts. This process highlighted punctate labeling of surface AMPARs in dendrites. Out-of-focus and extended, nondiscrete regions of staining were excluded from the quantitation. Integrated signal intensity values of surface AMPARs were determined for dendrites, normalized to area, and graphed as a ratio of labeling intensity of $0 \mathrm{~min}$ controls for each treatment condition. For all immunocytochemical analysis, $n$ refers to the number of experiments (with at least 10 cells per experiment). Statistical significance was determined using Student's $t$ test. Error bars represent SEM. Figure images were digitally processed using Adobe Photoshop (Adobe Systems, San Jose, CA).

\section{Results}

Rapid AMPAR cycling in cultured retinal neurons

To study constitutive AMPAR cycling, we adopted the strategy of recording responses to AMPA, while interrupting either endocytosis or exocytosis (Luscher et al., 1999). At synapses known to exhibit rapidly cycling AMPARs, the insertion and removal of 
receptors are dynamic and well balanced processes, so that the surface expression of receptors remains constant (Luscher et al., 1999). Therefore, if endocytosis is interrupted while exocytosis is left intact, AMPARs accumulate in the postsynaptic membrane, resulting in an increase of AMPAR-mediated responses. On the contrary, blocking exocytosis decreases surface AMPARs. To block the clathrin-mediated endocytosis of AMPARs, we first loaded cultured amacrine and ganglion cells (Fig. 1 $A$ ) with GDP- $\beta$ S to inhibit the GTPase activity of dynamin (Luscher et al., 1999). In these cells, responses ran up $2.61 \pm 0.29$-fold in $20 \mathrm{~min}$, implying that a large internal pool of AMPARs was inserted into the membrane (Fig. $1 B$ ). In a control group dialyzed with GTP, AMPA-induced responses were stable $(1.06 \pm 0.02)$ (Fig. $1 B$ ) during the time of recording, suggesting under these conditions, the rates of exocytosis and endocytosis are balanced.

We observed similar results when we used a dynaminblocking peptide to specifically block endocytosis. This 10 amino acid peptide, containing the proline-enriched domain of dynamin, was used to disrupt the interaction of dynamin with amphiphysin. Dialysis of cells with the dynamin peptide caused a run-up of $2.06 \pm 0.28$-fold (Fig. $1 B$ ). In complementary experiments, we used the light chain of botulinum toxin type B (BnTx) to inactivate vesicular $N$-ethylmaleimide-sensitive factor (NSF) attachment protein receptors and inhibit exocytosis of AMPARs (Luscher et al., 1999). AMPA responses decreased to $0.54 \pm 0.08$ of the original size with BnTx within 20 min (Fig. $1 B$ ). These results indicate that, as in CA1 pyramidal cells, surface expression of AMPARs in retina is a dynamic process in which receptors are constitutively inserted into and removed from the postsynaptic membrane.

Activity-regulated AMPAR trafficking in cultured retinal cells We wondered whether AMPAR cycling might be modulated by excitatory input, as has been demonstrated in other brain regions (Ehlers, 2000; Lin et al., 2000). Because GABAergic amacrine cells are the predominant cell type in our cultures, the synapses formed between cells are mostly inhibitory. Consistent with this, we rarely observed any excitatory synaptic input detected as spontaneous EPSCs (sEPSCs) in neurons from these cultures. It has been found that sEPSCs in retinal ganglion and amacrine cells are mediated purely by AMPARs (Taylor et al., 1995; Matsui et al., 1998). We therefore attempted to increase excitatory input by adding a low concentration of AMPA $(10 \mu \mathrm{M})$ to the cultures together with $50 \mu \mathrm{M}$ APV. For those cells treated with AMPA and APV for $<6 \mathrm{~h}$, we found that GDP- $\beta$ S caused a run-up of AMPA responses as before $(2.02 \pm 0.14)$ (Fig. $2 A)$. However, when we incubated cells with AMPA and APV overnight (16-20 h), AMPA responses remained constant $(0.93 \pm 0.09)$ during a 20 min period of recording. This inhibition of cycling was not apparently linked to a significant change in the basal expression of surface AMPARs, because we did not observe any effect on the average initial amplitude of AMPAR responses (AMPA $<6 \mathrm{~h}$, $63.7 \pm 25.9 \mathrm{pA}$; AMPA $>6 \mathrm{~h}, 63.29 \pm 10.4 \mathrm{pA})$ These results show that activating AMPARs over time can decrease their trafficking rates.

As an alternative method for increasing excitatory activity, we seeded the cultures with glutamatergic hippocampal neurons. We used the lipophilic membrane dye CM-diI to label retina cells before adding hippocampal cells, allowing us to identify selectively retinal cells. In these cocultures, sEPSCs appeared at $\sim 8$ DIV, implying synapse formation. At 11 DIV, 50\% of cells had sEPSCs, and at $14 \mathrm{DIV},>90 \%$ of cells received synaptic input. The amplitudes of responses to applied AMPA were not signifi-
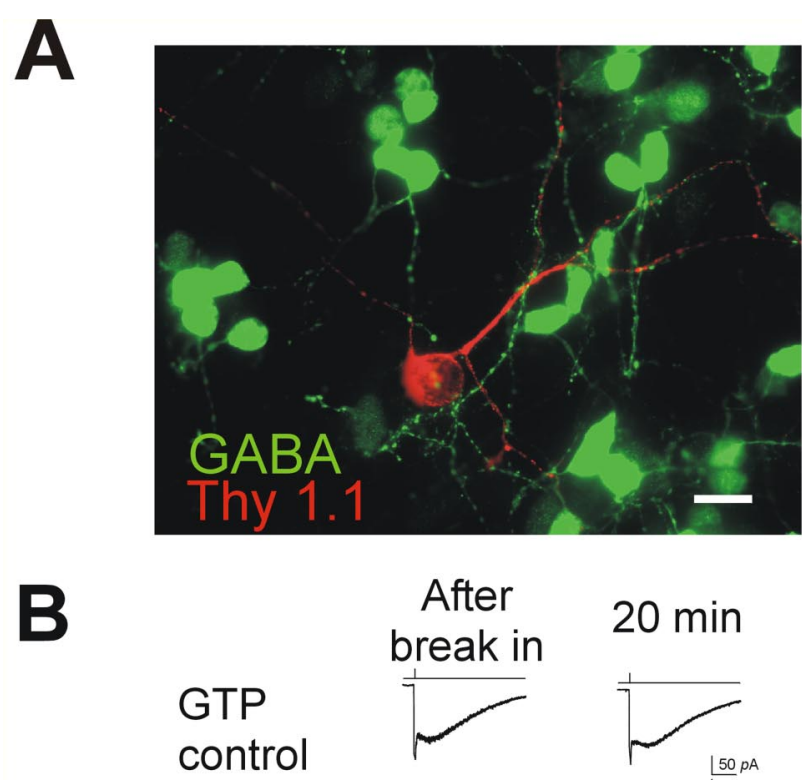

$20 \min$

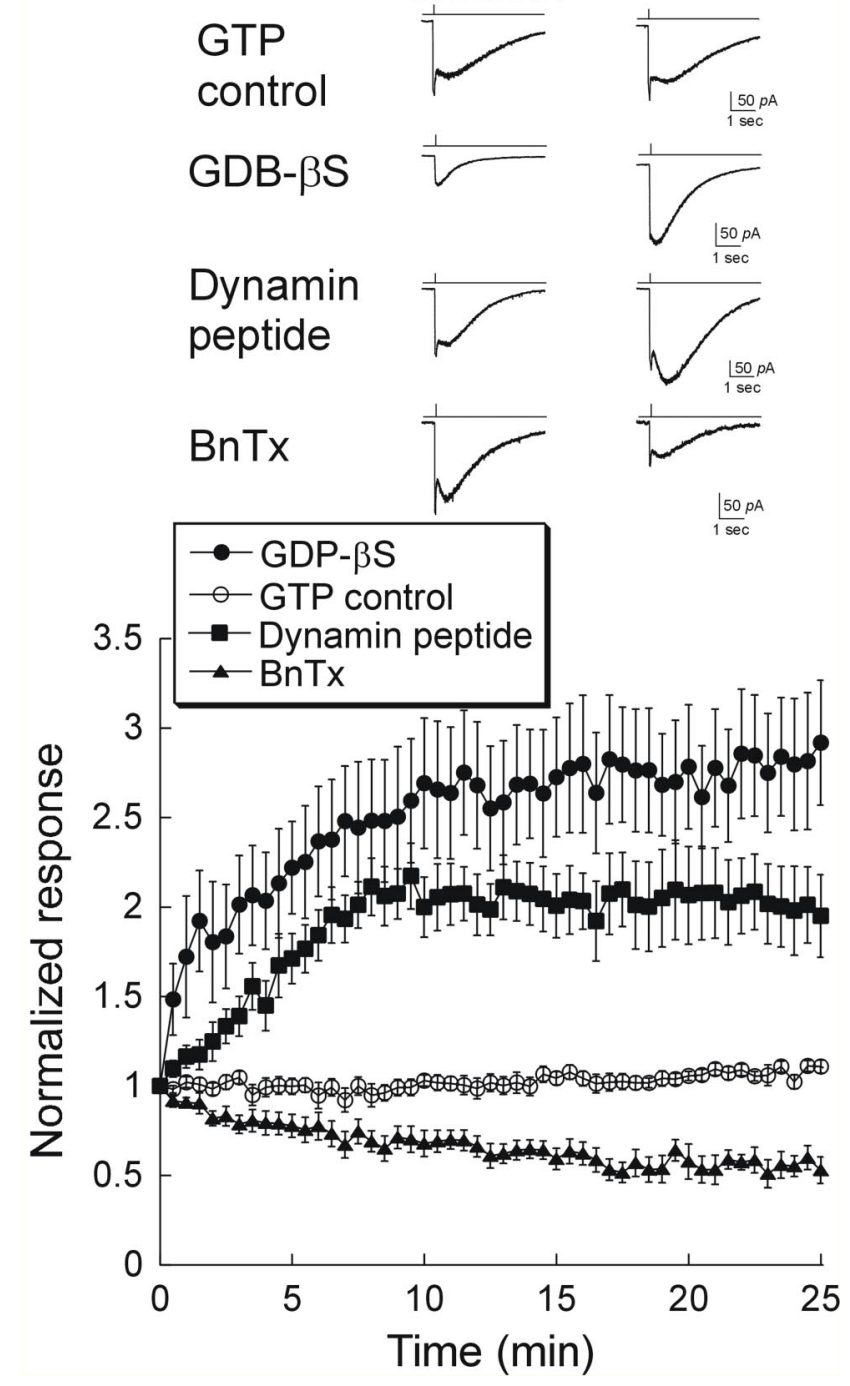

Figure 1. Rapid AMPAR trafficking in cultured retinal neurons. $\boldsymbol{A}$, Thy 1.1 (red) and GABA (green) double staining of cultured retinal neurons. Of 57 cells labeled with Thy1.1 (a marker for ganglion and displaced amacrine cells), only six cells were GABA negative, suggesting that this culture is dominated by amacrine cells. Scale bar, $10 \mu \mathrm{m}$. B, Bottom, Mean and SEM of the amplitude of the responses to puffs of AMPA in cells dialyzed with 1 mм GTP (open circles; $n=$ 12), $1 \mathrm{~mm} \mathrm{GDP-} \beta$ S, a nonhydrolyzable GTP analog (filled squares; $n=7$ ), $200 \mu \mathrm{g} / \mathrm{ml}$ dynamin blocking peptide (filled circles; Q-V-P-S-R-P-N-R-A-P-C terminal; $n=7$ ), or $0.5 \mu \mathrm{m}$ BnTx (filled triangles; $n=6$ ). Top, AMPA induced responses immediately after break-in (left) and $20 \mathrm{~min}$ later (right) in cells dialyzed with GTP, GDP- $\beta$ S, dynamin inhibitory peptide, or BnTx. 

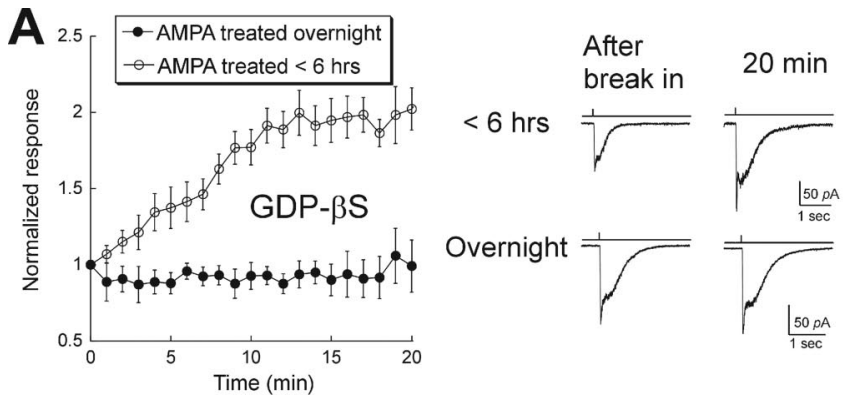

B
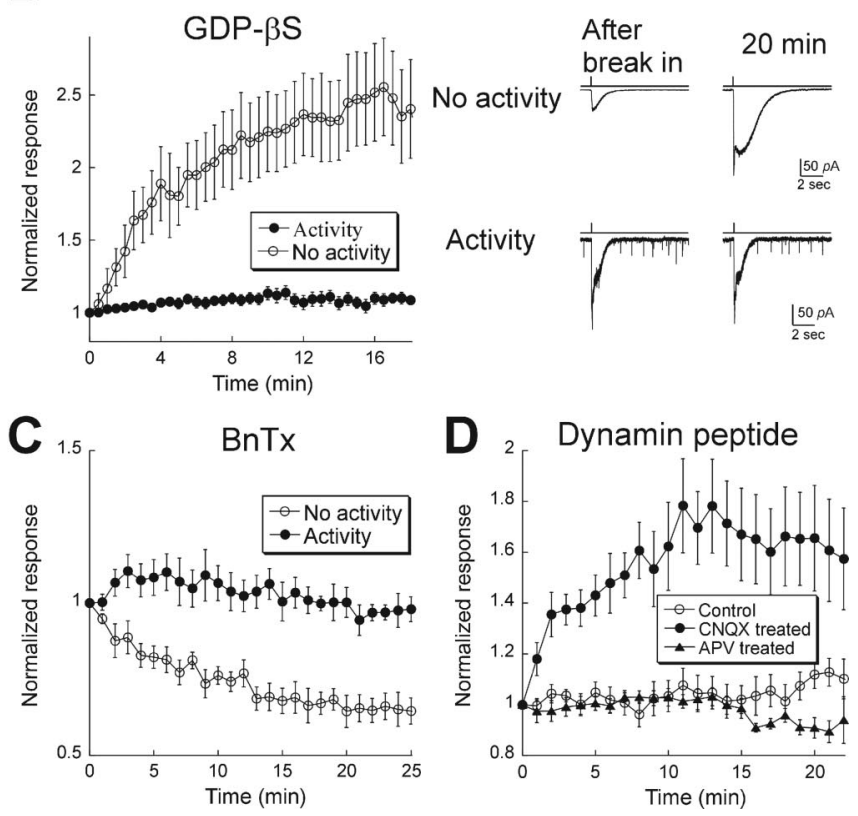

Figure 2. AMPAR trafficking rate is decreased by excitatory activity. $A$, Left, Cultured retinal neurons were incubated with $10 \mu \mathrm{M}$ AMPA and $50 \mu \mathrm{M}$ APV overnight (filled symbols; $n=5$ ) or for $<6 \mathrm{~h}$ (range, $1-5 \mathrm{~h}$; open symbols; $n=11$ ). Right, Examples of responses after break-in (left) and 20 min later under each condition. $\boldsymbol{B}$, Retinal-hippocampal cocultures. Left, Summary of results for cells with (filled symbols; $n=19$ ) or without (open symbols; $n=13$ ) sEPSCs. All cells were dialyzed with GDP- $\beta$ S. Right, Records taken from two cells, one with and the other without excitatory synaptic activity. Records were obtained at break-in and $20 \mathrm{~min}$ later. Note the presence of sEPSCs in the bottom panel. C, Summary of results from cells in retinal-hippocampal cocultures dialyzed with BnTx. In those cells with spontaneous EPSCs, BnTx had no effect, as expected in the absence of rapid AMPAR cycling (filled symbols; $n=5$ ). Conversely, in cells without spontaneous EPSCs, BnTx produced a time-dependent depression of the response to AMPA puffs (open symbols; $n=5$ ). $\boldsymbol{D}$, Mixed retinal-hippocampal cultures were incubated overnight in media alone (control; open circles; $n=19$ ) or media containing $50 \mu \mathrm{M}$ CNQX (filled circles; $n=11$ ) or $50 \mu$ M APV (filled triangles; $n=7$ ). Inhibition of AMPARs, but not NMDARs, was sufficient to restore rapid AMPAR cycling. Error bars represent SEM.

cantly different in cells with and without spontaneous activity, suggesting that activity did not have a large effect on total surface AMPAR expression (no sEPSCs, $142.96 \pm 25.9$ pA; with sEPSCs, $194.47 \pm 31.5 \mathrm{pA})$. Responses were stable in those cells with spontaneous EPSCs when probed with GDP- $\beta S(1.04 \pm 0.05)$ (Fig. $2 B$ ), the dynamin inhibitory peptide (1.12 \pm 0.06$)$ (Fig. $2 D)$, or BnTx $(0.93 \pm 0.08)$ (Fig. $2 C)$. However, in retinal neurons that lacked excitatory synaptic input in mixed retina-hippocampal cultures, as indicated by the absence of sEPSCs, there was significant run-up of the AMPA response in the presence of GDP- $\beta S$ (2.40 \pm 0.34$)$. Conversely, dialysis of BnTx led to a run-down of the responses ( $0.65 \pm 0.04$ of the initial response), as was demonstrated above for pure retina cultures. Thus activation of AMPARs, with either synaptic activity or exogenous AMPA, is sufficient to suppress trafficking in retinal neurons.

We found that AMPAR cycling could be bidirectionally regulated. After 14 DIV, when sEPSCs were present in nearly all cells, cultures were incubated with $50 \mu \mathrm{M}$ CNQX overnight, and coverslips were transferred to the recording chamber and rinsed thoroughly to wash out any residual CNQX, as evidenced by the reappearance of synaptic activity in CNQX-treated cells. Blocking synaptic activity overnight with CNQX induced a run-up of AMPAR-mediated responses when endocytosis was inhibited $(1.65 \pm 0.18)$ (Fig. 2D), indicating that cycling was restored. On the other hand, responses were stable $(0.91 \pm 0.03)$ when we blocked activation of NMDA receptors (NMDARs) with overnight application of $50 \mu \mathrm{M}$ APV (Fig. 2D). Thus, inhibition of AMPARs but not NMDARs is sufficient to induce rapid AMPAR cycling.

A second approach to studying receptor trafficking is to visualize the receptors directly by immunostaining. We focused on the GluR2 AMPAR subunit, because in other brain regions, GluR2-containing AMPARs are thought to be targeted for constitutive cycling (Passafaro et al., 2001; Shi et al., 2001; Esteban et al., 2003). Surface AMPARs were labeled in live neurons. After wash-off of antibody, cells from the same group of coverslips were incubated at $37^{\circ} \mathrm{C}$ for different periods of time and then lightly fixed, and the remaining surface AMPARs were stained with a fluorescence-conjugated secondary antibody. In cells with rapid AMPAR cycling, labeled surface receptors are endocytosed and replaced by unlabeled receptors, resulting in a decrease in fluorescence. Consistent with this, cells fixed after a $45 \mathrm{~min}$ incubation had only $0.21 \pm 0.09$ of surface fluorescence compared with cells fixed right after primary antibody staining (Fig. 3). However, after overnight incubation in AMPA, surface receptor labeling of GluR2 showed that $74 \pm 24 \%$ of receptors remained on the surface after $45 \mathrm{~min}$ in cultures, indicating a decrease in the rate of exocytosis. Collectively, our data suggest that AMPARs trafficking in retina is regulated by excitatory synaptic activity.

\section{PICK1/GRIP maintain AMPARs away from the membrane surface in cycling neurons}

The interaction of PICK1 and GRIP have been implicated in the endocytosis and reinsertion of actively internalized AMPARs into the membrane in the hippocampus (Daw et al., 2000; Xia et al., 2000; Kim et al., 2001; Lu and Ziff, 2005), although their role in constitutive AMPAR cycling is less clear. We therefore tested whether the interaction of GRIP or PICK with GluR2 might be involved in the rapid cycling of AMPARs in the retina. In retina, GRIP expression has been reported (Ghosh et al., 2001; Gabriel et al., 2002), and we also observed PICK1 staining in retinal cultures (Fig. 4A).

We introduced through our recording pipette a peptide encoding the PDZ (postsynaptic density-95/Discs large/zona occludens-1) binding domain of the GluR2 C terminus (pep2SVKI) that interrupts the binding of GluR2 with PICK1/GRIP (Daw et al., 2000; Xia et al., 2000; Kim et al., 2001). In cells that received synaptic input, dialyzing with SVKI peptide did not cause any change in the AMPA response (Fig. $4 B$ ). We then incubated cells with CNQX overnight to promote cycling; these cells now exhibited a significant run-up (1.48 \pm 0.14$)$ of AMPA responses when SVKI was included in the pipette. Our results imply that in cycling retinal cells, some GluR2 receptors are held inside by PICK and/or GRIP; after dissociation from them, GluR2 receptors are inserted into the membrane surface, thus causing an increase in the AMPA response. 

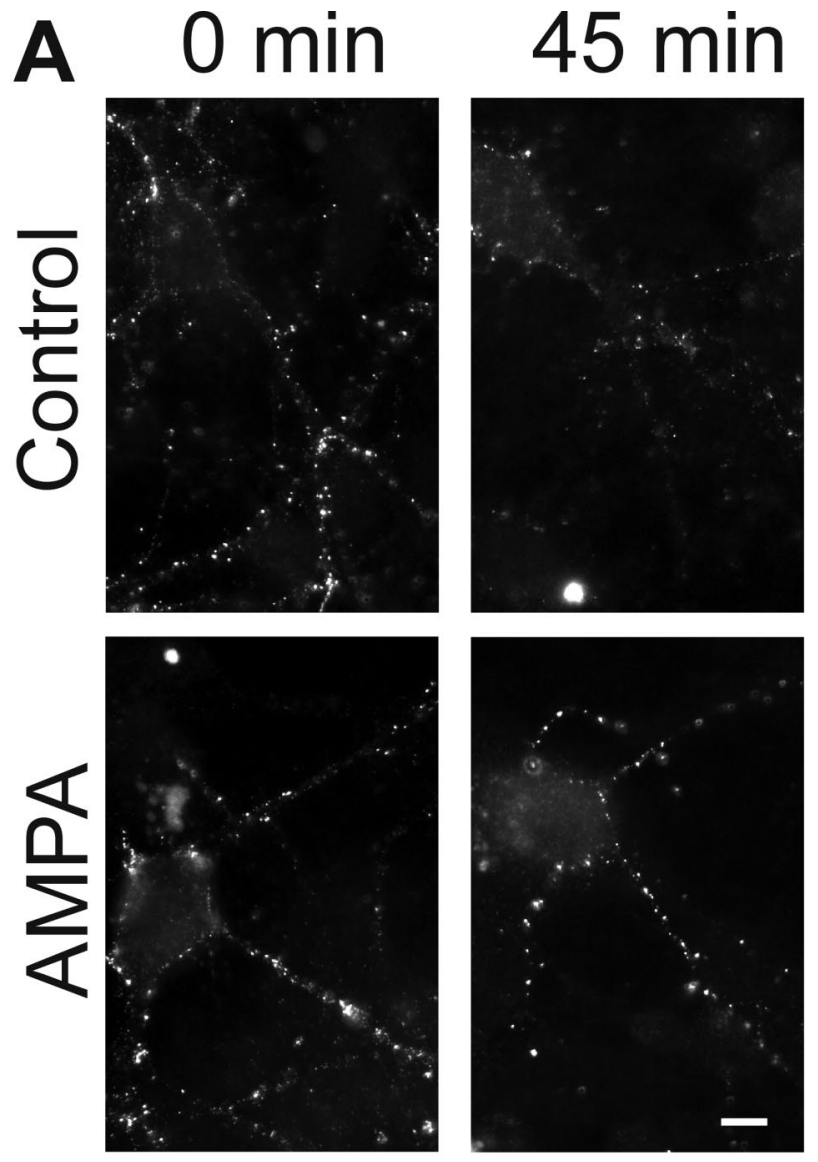

B

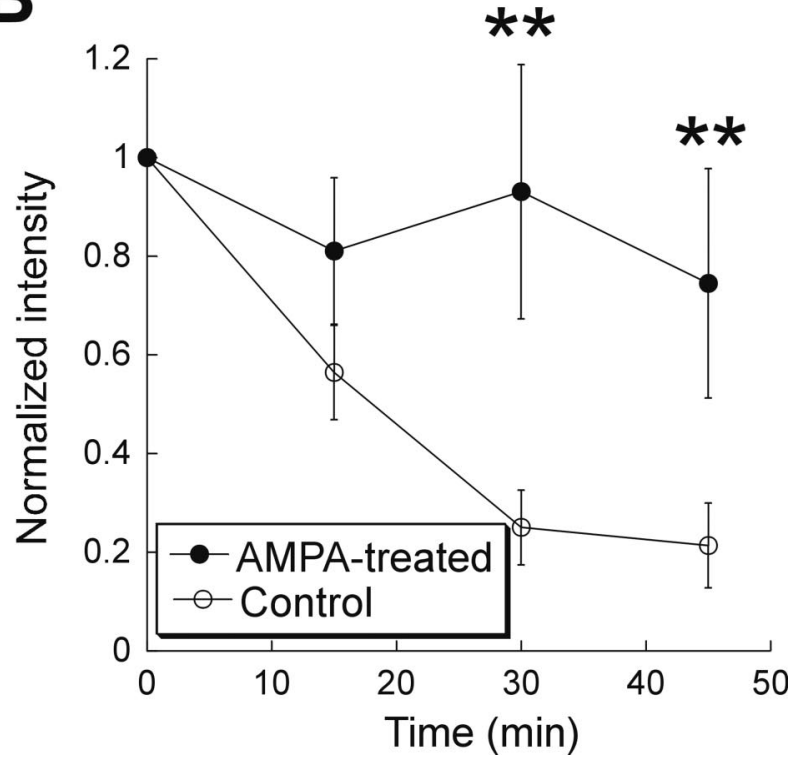

Figure 3. Immunohistochemical evidence for activity-dependent cycling of GluR2containing AMPARs in cultured retinal neurons. $\boldsymbol{A}$, Cultured retinal neurons were incubated with an antibody recognizing the extracellular epitope of GluR2 for $30 \mathrm{~min}$ and washed thoroughly. Cells were fixed immediately ( 0 min; left) or were incubated in complete media for 45 min before fixation and secondary antibody application (right). In a control group (top), surface staining was decreased, whereas there was little internalization in cells treated with AMPA overnight (bottom). Scale bar, $5 \mu \mathrm{m}$. $\boldsymbol{B}$, Summary of the results from five experiments in the control group and four experiments in the AMPA-treated group. ${ }^{* *} p<0.01$. Error bars represent SEM.

A $\quad$ PICK1

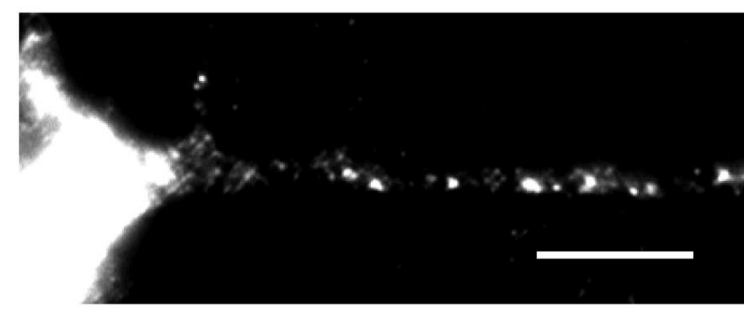

B

\section{pep-SVKI}

After break in
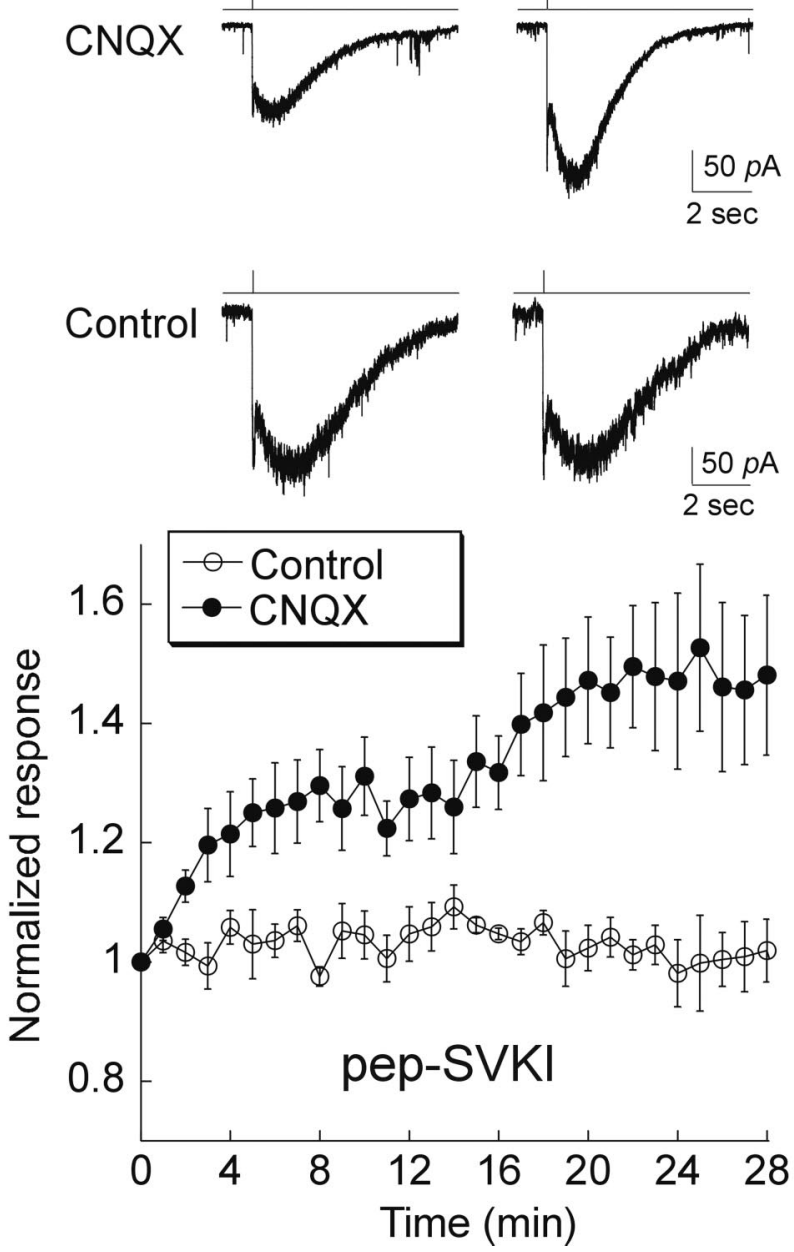

Figure 4. Cycling of GluR2 AMPARs in retinal neurons is also regulated by PICK/GRIP. $\boldsymbol{A}$, PICK1 protein was detected by immunocytochemical labeling in 2-week-old cultured retinal neurons. Scale bar, $10 \mu \mathrm{m}$. $\boldsymbol{B}$, Top, Records obtained from retinal neurons maintained in hippocampal-retinal cocultures. Inclusion of the GRIP/PICK1 inhibitory peptide (pep2-SVKI) in the recording pipette resulted in a run-up of the AMPA response in CNQX-treated, but not control, cultures. Bottom, Summary of results: control group, $n=6$ (open circles); CNQX treated, $n=12$ (filled circles). Inhibition of PICK/GRIP had no effect on AMPARs in noncycling neurons but released receptors to the surface in cycling neurons. Error bars represent SEM.

AMPARs do not rapidly cycle in intact light-adapted retinas Thus far, we have reported that AMPARs in cultured retinal amacrine cells exist in either a rapidly cycling state or a state in which they cycle very slowly, or perhaps not at all. The state depends on 
A
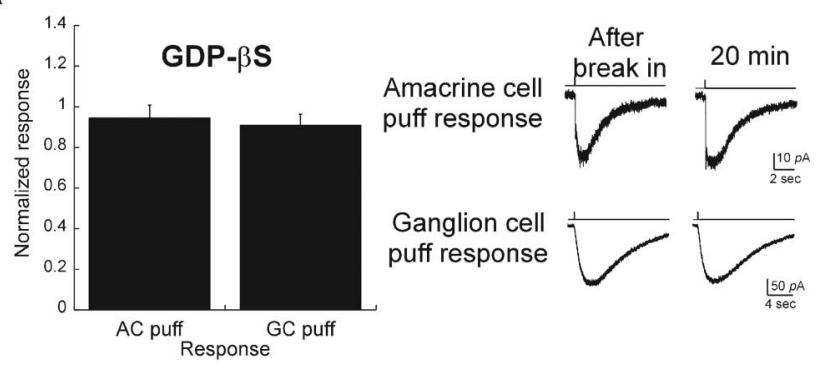

B
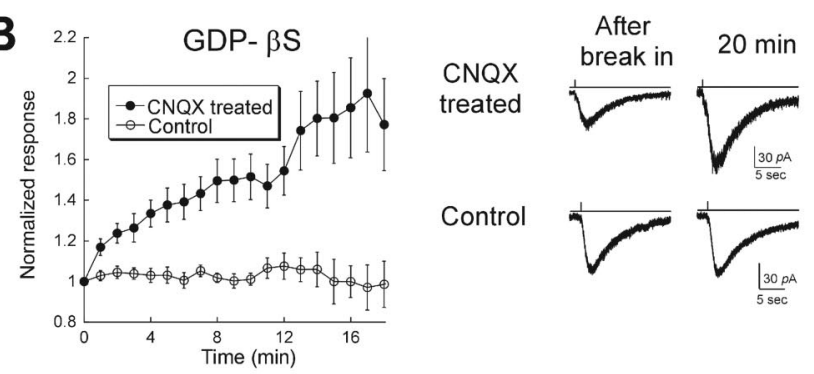

C
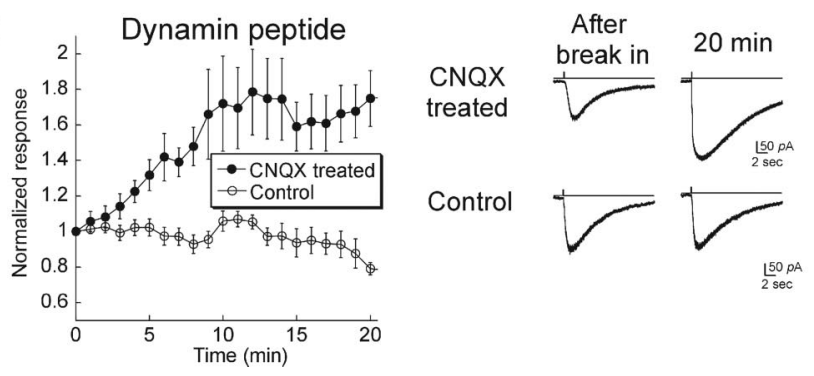

$\frac{150}{2 \mathrm{sec}}$

Figure 5. Blocking activity in intact retina induces rapid AMPAR cycling. $A$, Left, Summary of responses to puffs of AMPA in ganglion cells (GCs;n=29) and amacrine cells $(\mathrm{ACs} ; n=3)$ in light-adapted rat retina. All cells were held at $-65 \mathrm{mV}$ and dialyzed with $1 \mathrm{~mm}$ GDP- $\beta$ S. Neither ganglion nor amacrine cells had significant rapid AMPAR turnover. Right, Example of responses after break-in (left) and $15 \mathrm{~min}$ later (right) for two responses (from top to bottom: amacrine cell puff, ganglion cell puff responses). $\boldsymbol{B}$, Ganglion cells from retinal explants were dialyzed with GDP- $\beta$ S to test for AMPAR trafficking. In a control group (open circles; $n=12$ ), AMPAmediated responses were stable. When retinas were incubated with 50-100 $\mu \mathrm{m}$ CNQX overnight to block ongoing activity (filled circles; $n=9$ ), GDP- $\beta$ S caused a run-up of 1.6-fold. $C$, Similar results in retina explants were obtained using the dynamin peptide ( $n=8$ for control; $n=10$ for (NQX-treated explants). Error bars represent SEM.

the level of AMPAR activation, because increasing the tone of activity switches receptors to the noncycling state. We wanted to address whether this type of plasticity also exists in the intact retina.

Because our culture data were derived primarily from amacrine cells, we first puffed AMPA onto amacrine cells from retina slices and dialyzed them with GDP- $\beta$ S. During recordings of up to $20 \mathrm{~min}$, no change in the responses to puff of AMPA was observed $(0.95 \pm 0.06)$ (Fig. $5 A)$. We similarly recorded from ganglion cells in the whole-mount preparation and measured responses to puffs. No run-up was observed in this cell type either $(0.91 \pm 0.05)$. The absence of cycling in amacrine and ganglion cells of the intact retina, which exhibit significant levels of glutamate release, is consistent with our hypothesis that the AMPAR cycling rate is inhibited in the presence of sustained activity.

\section{Blocking activity induces AMPAR cycling in intact retina}

Our culture data predict that rapid trafficking might be induced in intact retinas when excitatory synaptic activity is blocked. To test this, we first made explants of intact retinas and incubated them with or without CNQX for up to $18 \mathrm{~h}$ and then recorded AMPA-elicited responses. GDP- $\beta S$ or the dynamin peptide was included in the internal solution to monitor AMPAR cycling. In retinas incubated in control media, neither GDP- $\beta$ S $(0.99 \pm$ $0.01)$ nor dynamin peptide $(0.79 \pm 0.04)$ induced any increase in the AMPA response, suggesting that trafficking of AMPARs in explants is the same as in freshly isolated retinas. However, when we added $100 \mu \mathrm{M}$ CNQX to the culture media overnight to block activation of AMPARs, GDP- $\beta$ S induced a run-up of AMPA responses $(1.79 \pm 0.23$ of the initial response) (Fig. $5 B$ ), whereas the dynamin peptide produced a $1.75 \pm 0.15$-fold increase (Fig. $5 C)$. Thus, in the intact retina as well as in cultures, decreasing activity switches AMPARs into a cycling mode.

\section{Visual stimulation regulates AMPAR trafficking}

We next tested whether reducing synaptic activity through mechanisms that are intrinsic to the retina would have a similar effect on AMPAR cycling. Specifically, we tested the possibility that eliminating visual input might sufficiently reduce excitatory activity to switch AMPAR cycling states. Accordingly, mice were deprived of light for periods of 12-48 h. Dark-adapted retinas were then isolated under infrared illumination and responses to puffs of AMPA were obtained from ganglion cells that were dialyzed with dynamin inhibitory peptide. To isolate AMPARmediated responses in intact retinas, and to prevent activation of inhibitory circuits, cells were held at $-65 \mathrm{mV}$ and bathed with a mixture of antagonists including bicuculline $(100 \mu \mathrm{M}$; a GABA receptor antagonist), TPMPA [(1,2,5,6-tetrahydropyridin-4yl)methylphosphinic acid; $50 \mu \mathrm{M}$; a $\mathrm{GABA}_{\mathrm{C}}$ receptor antagonist], strychnine ( $1 \mu \mathrm{M}$; a glycine receptor antagonist), picrotoxin (100 $\mu \mathrm{M}$; a GABA receptor antagonist), and APV (50 $\mu \mathrm{M}$; a NMDA receptor antagonist). Cells were characterized as $\mathrm{ON}$, $\mathrm{OFF}$, or ON-OFF according to their responses to steps of light.

AMPA puff responses in eight OFF ganglion cells that were dialyzed with the dynamin peptide showed no significant changes over $20 \mathrm{~min}(0.97 \pm 0.07)$, indicating a lack of AMPAR cycling in OFF cells after light deprivation (Fig. 6A). However, in five of five ON ganglion cells, inhibition of endocytosis potentiated the AMPA puff response by an average of $35 \pm 8 \%$. A third class of ganglion cells, the ON-OFF cells, produced mixed results: six of 13 cells exhibited AMPAR cycling (Fig. 6). These findings are consistent with the hypothesis that activity inhibits AMPAR cycling: OFF bipolar cells are depolarized in darkness and release transmitter onto OFF ganglion cells at a high rate. On the other hand, there is considerably less activity in the ON pathway in the dark, because ON bipolar cells are hyperpolarized and the level of synaptic input to ON ganglion cells is low. Thus, our data suggest that changes in the levels of synaptic activity in response to physiological stimuli are sufficient to modulate AMPAR function in ganglion cells in a pathway-specific manner.

We also investigated the amount of time in darkness required to induce rapid trafficking in ON cells. When mice were dark adapted for $<8 \mathrm{~h}$, no run-up of the AMPA response was observed in $\mathrm{ON}$ or $\mathrm{ON}-\mathrm{OFF}$ cells that were dialyzed with the dynamin inhibitory peptide. However, $8 \mathrm{~h}$ or more in the dark caused run-up in all ON cells and in some ON-OFF cells (Fig. 7A). The amplitudes of run-up from cells reared in dark for 8-12 h (1.31 \pm $0.07)$ and those for $>12 \mathrm{~h}(1.31 \pm 0.06)$ were the same (Fig. $7 B)$. Thus, modulation of AMPAR cycling rate occurs within the range of a normal day/night cycle. 


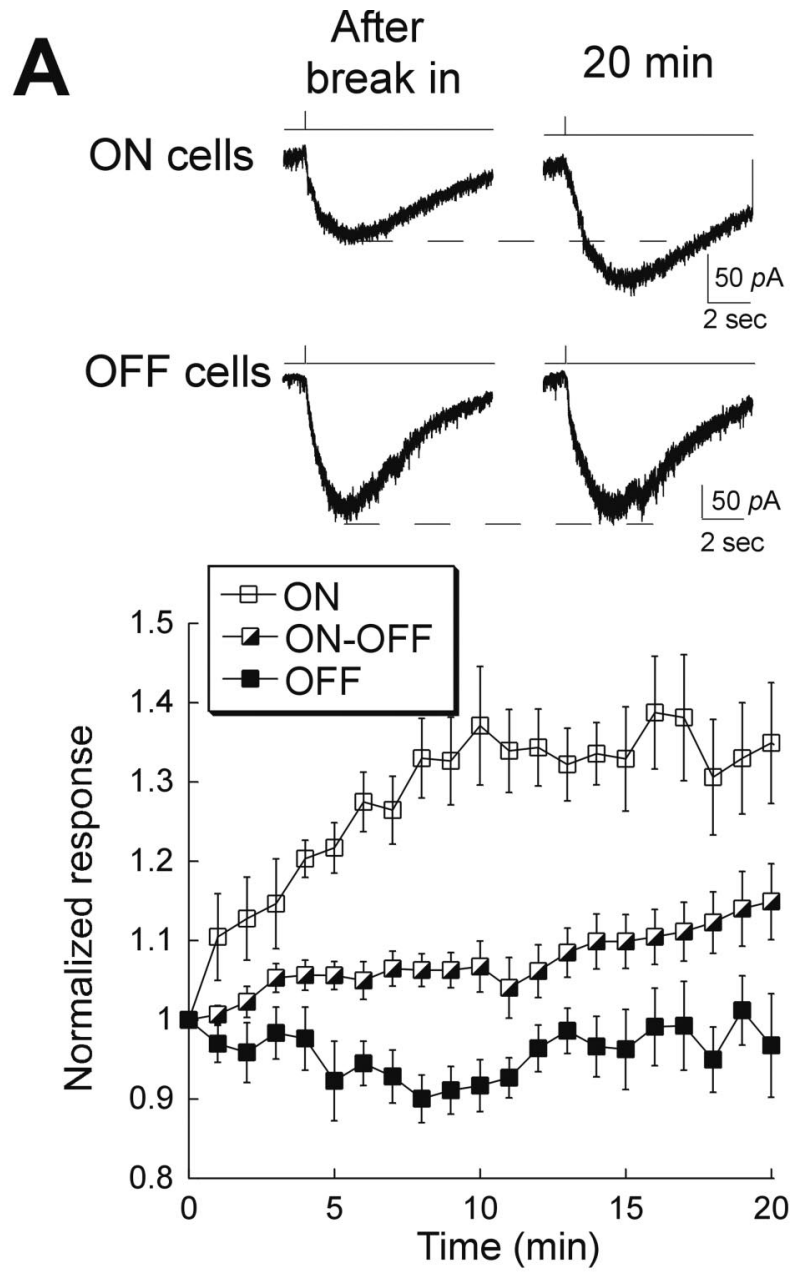

B

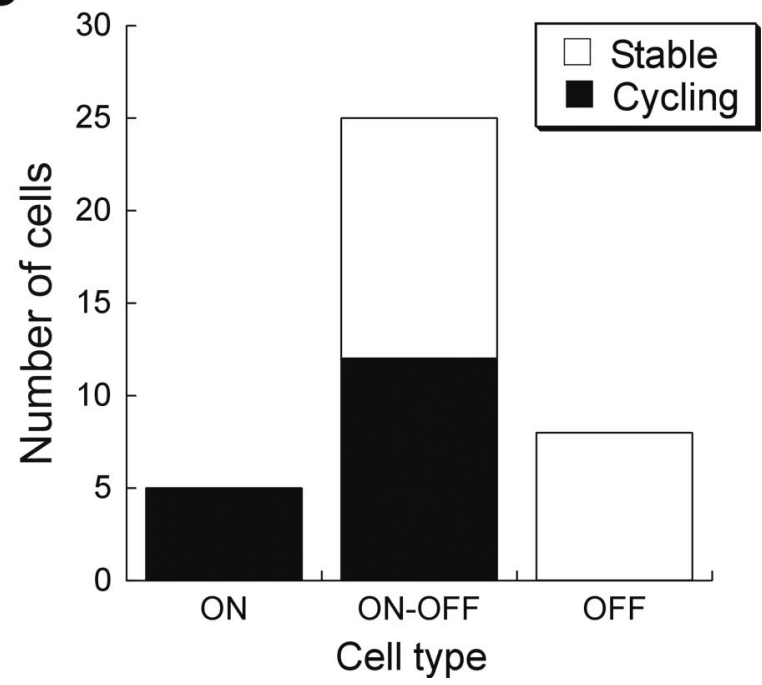

Figure 6. Light deprivation induces AMPAR trafficking in intact retinas. $A$, Top, Responses to AMPA puff at break-in and after $20 \mathrm{~min}$ in an $\mathrm{ON}$ and an OFF ganglion cell from animals that were kept in darkness for $>8 \mathrm{~h}$ before recording. The dynamin peptide was included in the recording pipette. Bottom, Summary of results, organized according to cell type. ON cell responses ran up to 1.3-fold (open squares; $n=5$ ), whereas OFF cell responses remained constant (filled squares; $n=6$ ). Run-up of $0 \mathrm{~N}-0 \mathrm{FF}$ cells (half-filled squares; $n=25$ ) was more variable. Error bars represent SEM. B, Histogram plotting the number of cells that ran up versus the number that remained stable, as a function of cell type. Run-up was defined as an increase of at least $10 \%$ relative to the initial response amplitude.
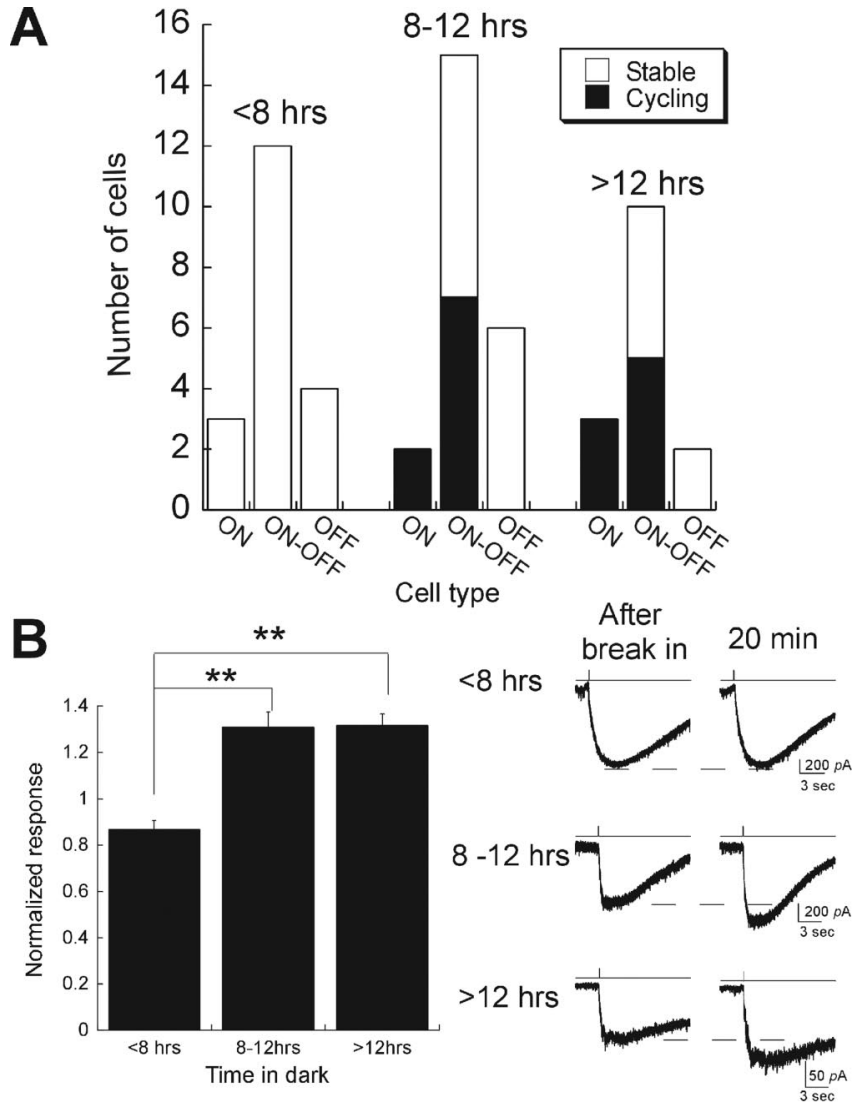

Figure 7. Induction of AMPAR trafficking in vivo needs as little as $8 \mathrm{~h}$ of light deprivation. $A$, Cycling was measured in retinas isolated from mice that were light deprived for various time periods. Dynamin peptide was dialyzed into ganglion cells to monitor changes of AMPA-elicited responses in $\mathrm{ON}, \mathrm{OFF}$, and $\mathrm{ON}-\mathrm{OFF}$ ganglion cells. The number of cells whose AMPAR-mediated responses ran up or remained stable are plotted for three time windows $(<8 \mathrm{~h}$, between 8 and $12 \mathrm{~h}$, and $>12 \mathrm{~h}$ ). $\boldsymbol{B}$, Left, Normalized responses of all ON cells and those ON-OFF cells that displayed run-up after $20 \mathrm{~min}$ of intracellular application of the dynamin inhibitory peptide, plotted as a function of the length of dark adaptation ( $\angle 8 \mathrm{~h}, n=30 \mathrm{~N}$ cells; $8-12 \mathrm{~h}, n=20 \mathrm{~N}$ cells and $70 \mathrm{~N}-0 \mathrm{FF}$ cells; $>12 \mathrm{~h}, n=30 \mathrm{~N}$ cells and $50 \mathrm{~N}-\mathrm{OFF}$ cells). Asterisks indicate significance of $p<0.01$. Error bars represent SEM.

\section{Discussion}

In the past several years, evidence from hippocampus (Luscher et al., 1999; Luthi et al., 1999; Malinow and Malenka, 2002) and cortex (Lu et al., 2003; Takahashi et al., 2003; Tomita et al., 2004) has revealed that AMPARs can undergo rapid cycling and has suggested that this cycling is as an important regulatory mechanism. Specifically, it is thought that this form of AMPAR trafficking provides a means for fast, regulated changes in synaptic AMPAR number or composition (Turrigiano, 2000; Lee et al., 2004). In the present study, we presented evidence that retinal neurons are similarly capable of undergoing rapid cycling. However, we find that the expression of AMPAR cycling is conditional on synaptic activity levels. Furthermore, cycling is turned on and off in response to naturally occurring physiological stimuli, the first time such a link has been made to AMPAR cycling. These results suggest that glutamatergic signaling in the inner retina is likely to be more plastic than previously believed and demonstrates the diversity by which mechanisms link activity to receptor trafficking. Plasticity of synaptic input to ganglion cells has been postulated to play an important role in the dynamic modulation of spatio-temporal receptive field properties of ganglion cells (Hosoya et al., 2005). 


\section{Regulation of AMPAR trafficking in retina}

Increased glutamatergic signaling in retinal neurons switches AMPARs into a noncycling state. The mechanism by which this switch occurs is of particular interest because this finding is in apparent contrast to studies of cultured cortical and hippocampal neurons, which demonstrate that increasing glutamatergic signaling promotes AMPAR cycling (Ehlers, 2000; Lin et al., 2000). The extent of AMPAR activation in these cell types could contribute to differences in effects on cycling. Glutamate release is tonic and graded in the inner plexiform layer, whereas spontaneous release in the hippocampus and cortex is intermittent. However, the ability of cocultured hippocampal neurons to inhibit cycling indicates that even sporadic, spontaneous activation of AMPARs alone is sufficient to drive changes in trafficking in retinal neurons.

Different effects of activity on cycling could alternatively stem from the type of activated glutamate receptor in the various systems. In the retina, AMPA and CNQX bidirectionally influence receptor turnover, demonstrating the importance of AMPARs in mediating this process. The activation of NMDARs, in contrast, has been implicated in the enhancement of cycling in cortical and hippocampal neurons (Ehlers, 2000; Lin et al., 2000). However, even in those cells, there appears to be an NMDAR-independent, likely AMPAR component, which contributes to the enhancement of AMPAR cycling. Unlike cortical and hippocampal neurons, which predominantly express GluR2-containing AMPARs, retinal neurons also express significant levels of GluR2-lacking AMPARs (Singer and Diamond, 2003), and activation of these receptors themselves would be expected to result in an influx of $\mathrm{Ca}^{2+}$ that might influence AMPAR trafficking. In fact, in cerebellar stellate cells, activation of GluR2-lacking channels has been shown to modulate AMPAR trafficking (Liu and Cull-Candy, 2000, 2002); a similar triggering mechanism may occur in the retina.

\section{PICK/GRIP proteins in retina}

Our results from retinal neurons showed that PICK1/GRIPdependent regulation of AMPARs is only present in cells exhibiting active receptor cycling. This is consistent with studies that suggest the importance of PICK1 and/or GRIP in cycling. In the absence of PICK1/GRIP binding, AMPAR cycling is significantly reduced in cultured hippocampal neurons (Passafaro et al., 2001). A recent study (Lu and Ziff, 2005) further suggests that AMPAR recycling requires the interaction of PICK with a bound ABP/GRIP-AMPAR complex to free the receptor, allowing it to return to the cell surface. In cerebellar stellate cells, a similar model suggests a role for PICK1 in recycling GluR2-containing receptors back to the membrane surface (Gardner et al., 2005). It seems likely, therefore, that in the retina, the PICK1/GRIP mechanism is upregulated in the absence of activity, thereby inducing the cycling of AMPARs.

The induction of rapid cycling may be mediated by several mechanisms including altering the function, localization, or expression of PICK and/or GRIP proteins. One model of PICK/ GRIP-mediated cycling suggests that GRIP may stabilize AMPARs at the cell surface or intracellularly (Henley, 2003). PICK1 mediates the unbinding of GluR2/3 from GRIP, in part by positioning $\mathrm{PKC}$ to phosphorylate the $\mathrm{C}$ terminus of GluR2/3, which reduces its affinity for GRIP (Perez et al., 2001). PICK1 can then bind to GluR2/3 and move it into a mobile population of receptors. To enable synaptic insertion of GluR2s, NSF must bind to GluR2, where it can facilitate the unbinding of PICK1 (Hanley et al., 2002; Beretta et al., 2005). The localization of PICK1, the phosphorylation of GluR2, and the activation of NSF are all steps that may be subject to regulation by synaptic activity. However, light deprivation of at least $8 \mathrm{~h}$ is required to induce rapid trafficking of AMPARs in the retina. The time course of this change seems most consistent with a change in protein expression, potentially of PICK1 or GRIP themselves, which could subsequently modulate AMPAR trafficking.

\section{Light modulation of AMPAR cycling}

As little as $8 \mathrm{~h}$ of light deprivation causes a maximal increase in the rapid cycling of AMPARs in ON cells, whereas ON cells from animals that were deprived of light for even a few hours shorter than this time point showed no cycling. Thus, the switch for cycling can be triggered during the time course of a normal day/ night cycle. On the other hand, light deprivation had no effect on AMPAR cycling in the OFF pathway. Because CNQX was found to induce cycling of OFF ganglion cells, it is likely that AMPAR trafficking in OFF ganglion cells is similarly regulated by activity as it is in ON ganglion cells. However, we never observed evidence of cycling in OFF cells in animals that were continuously exposed to room light. This might indicate that synaptic activity in the OFF pathway elicited by normal changes in the visual scene is sufficient to inhibit cycling. This is perhaps not surprising, because activity in the OFF pathway is likely to be highly dynamic even in constant light because of events such as eye closing and eye covering. Constant exposure of the retina to light of a fixed intensity would be predicted to drive receptor trafficking in the OFF ganglion cells, but this scenario is not easily tested experimentally and would be extremely rare in everyday life.

\section{Does AMPA cycling imply the presence of synaptic plasticity?}

What is the role of AMPAR cycling in retina? An intriguing possibility is that the cycling state may place synapses in a mode that is primed for activity-mediated plasticity. In hippocampus, rapid receptor turnover maintains a steady population of synaptic AMPARs. It has been proposed that a regulated change in the balance between endocytosis and exocytosis could consequently allow for changes in synaptic strength (Turrigiano, 2000; Lee et al., 2004). The appropriate stimulus in retinal neurons undergoing receptor cycling, if comparable with other systems, could mediate rapid changes in synaptic AMPAR numbers, a form of synaptic plasticity not identified previously at these synapses.

Another possibility is that cycling provides a mechanism to change the subunit composition of AMPARs. Recent studies in cerebellar stellate cells show that synaptic stimulation induces replacement of GluR2-lacking receptors with GluR2-containing receptors, thus changing calcium signaling as well as the strength of synaptic input (Liu and Cull-Candy, 2000, 2002, 2005; Gardner et al., 2005). Unlike in hippocampus, where synaptic AMPARs primarily express GluR2-containing AMPARs, retinal neurons often express GluR2-lacking AMPARs (Singer and Diamond, 2003). The involvement of proteins that bind to GluR2/ GluR3 receptors in the cycling of AMPARs suggests that the induction of AMPAR trafficking may alter the surface population of GluR2-containing AMPARs. Cycling AMPARs could be comprised of a new population of GluR2-containing receptors that are introduced into the dendritic regions after the cessation of activity. Alternatively, an upregulation of cycling machinery could reduce surface GluR2s found at the membrane by increasing the proportion of AMPARs stabilized in intracellular compartments.

Long-term plasticity such as long-term potentiation and LTD is thought to be an important mechanism for learning and mem- 
ory and is preferentially induced in restricted periods of development. We have presented evidence that rapid AMPAR cycling, linked to synaptic plasticity at other synapses, can be induced in the retina. If cycling is a prerequisite for long-term plasticity, our data suggest that in the retina, synaptic plasticity may also be induced in restricted time periods but that these occur for brief periods that change with the light/dark cycle of a normal day. Further understanding of this process will shed light on our understanding of the function and regulation of visual system.

\section{References}

Beretta F, Sala C, Saglietti L, Hirling H, Sheng M, Passafaro M (2005) NSF interaction is important for direct insertion of GluR2 at synaptic sites. Mol Cell Neurosci 28:650-660.

Bredt DS, Nicoll RA (2003) AMPA receptor trafficking at excitatory synapses. Neuron 40:361-379.

Carroll RC, Beattie EC, von Zastrow M, Malenka RC (2001) Role of AMPA receptor endocytosis in synaptic plasticity. Nat Rev Neurosci 2:315-324.

Daw MI, Chittajallu R, Bortolotto ZA, Dev KK, Duprat F, Henley JM, Collingridge GL, Isaac JT (2000) PDZ proteins interacting with C-terminal GluR2/3 are involved in a PKC-dependent regulation of AMPA receptors at hippocampal synapses. Neuron 28:873-886.

Ehlers MD (2000) Reinsertion or degradation of AMPA receptors determined by activity-dependent endocytic sorting. Neuron 28:511-525.

Esteban JA, Shi SH, Wilson C, Nuriya M, Huganir RL, Malinow R (2003) PKA phosphorylation of AMPA receptor subunits controls synaptic trafficking underlying plasticity. Nat Neurosci 6:136-143.

Gabriel R, de Souza S, Ziff EB, Witkovsky P (2002) Association of the AMPA receptor-related postsynaptic density proteins GRIP and ABP with subsets of glutamate-sensitive neurons in the rat retina. J Comp Neurol 449:129-140.

Gardner SM, Takamiya K, Xia J, Suh JG, Johnson R, Yu S, Huganir RL (2005) Calcium-permeable AMPA receptor plasticity is mediated by subunitspecific interactions with PICK1 and NSF. Neuron 45:903-915.

Ghosh KK, Haverkamp S, Wassle H (2001) Glutamate receptors in the rod pathway of the mammalian retina. J Neurosci 21:8636-8647.

Hanley JG, Khatri L, Hanson PI, Ziff EB (2002) NSF ATPase and alpha-/ beta-SNAPs disassemble the AMPA receptor-PICK1 complex. Neuron 34:53-67.

Henley JM (2003) Proteins interactions implicated in AMPA receptor trafficking: a clear destination and an improving route map. Neurosci Res 45:243-254.

Hosoya T, Baccus SA, Meister M (2005) Dynamic predictive coding by the retina. Nature 436:71-77.

Kim CH, Chung HJ, Lee HK, Huganir RL (2001) Interaction of the AMPA receptor subunit GluR2/3 with PDZ domains regulates hippocampal long-term depression. Proc Natl Acad Sci USA 98:11725-11730.

Lee SH, Simonetta A, Sheng M (2004) Subunit rules governing the sorting of internalized AMPA receptors in hippocampal neurons. Neuron 43:221-236.

Lin JW, Ju W, Foster K, Lee SH, Ahmadian G, Wyszynski M, Wang YT, Sheng M (2000) Distinct molecular mechanisms and divergent endocytotic pathways of AMPA receptor internalization. Nat Neurosci 3:1282-1290.

Liu SJ, Cull-Candy SG (2002) Activity-dependent change in AMPA receptor properties in cerebellar stellate cells. J Neurosci 22:3881-3889.

Liu SJ, Cull-Candy SG (2005) Subunit interaction with PICK and GRIP controls $\mathrm{Ca}^{2+}$ permeability of AMPARs at cerebellar synapses. Nat Neurosci 8:768-775.

Liu SQ, Cull-Candy SG (2000) Synaptic activity at calcium-permeable AMPA receptors induces a switch in receptor subtype. Nature 405:454-458

Lu HC, She WC, Plas DT, Neumann PE, Janz R, Crair MC (2003) Adenylyl cyclase I regulates AMPA receptor trafficking during mouse cortical "barrel" map development. Nat Neurosci 6:939-947.

Lu W, Ziff EB (2005) PICK1 interacts with ABP/GRIP to regulate AMPA receptor trafficking. Neuron 47:407-421.

Luscher C, Xia H, Beattie EC, Carroll RC, von Zastrow M, Malenka RC, Nicoll RA (1999) Role of AMPA receptor cycling in synaptic transmission and plasticity. Neuron 24:649-658

Luthi A, Chittajallu R, Duprat F, Palmer MJ, Benke TA, Kidd FL, Henley JM, Isaac JT, Collingridge GL (1999) Hippocampal LTD expression involves a pool of AMPARs regulated by the NSF-GluR2 interaction. Neuron 24:389-399.

Malinow R, Malenka RC (2002) AMPA receptor trafficking and synaptic plasticity. Annu Rev Neurosci 25:103-126.

Matsui K, Hosoi N, Tachibana M (1998) Excitatory synaptic transmission in the inner retina: paired recordings of bipolar cells and neurons of the ganglion cell layer. J Neurosci 18:4500-4510.

Nawy S (1999) The metabotropic receptor mGluR6 may signal through $G_{o}$, but not phosphodiesterase, in retinal bipolar cells. J Neurosci 19:2938-2944.

Passafaro M, Piech V, Sheng M (2001) Subunit-specific temporal and spatial patterns of AMPA receptor exocytosis in hippocampal neurons. Nat Neurosci 4:917-926.

Perez JL, Khatri L, Chang C, Srivastava S, Osten P, Ziff EB (2001) PICK1 targets activated protein kinase $\mathrm{C} \alpha$ to AMPA receptor clusters in spines of hippocampal neurons and reduces surface levels of the AMPA-type glutamate receptor subunit 2. J Neurosci 21:5417-5428.

Sheng M, Lee SH (2001) AMPA receptor trafficking and the control of synaptic transmission. Cell 105:825-828.

Shi S, Hayashi Y, Esteban JA, Malinow R (2001) Subunit-specific rules governing AMPA receptor trafficking to synapses in hippocampal pyramidal neurons. Cell 105:331-343.

Singer JH, Diamond JS (2003) Sustained $\mathrm{Ca}^{2+}$ entry elicits transient postsynaptic currents at a retinal ribbon synapse. J Neurosci 23:10923-10933.

Takahashi T, Svoboda K, Malinow R (2003) Experience strengthening transmission by driving AMPA receptors into synapses. Science 299:1585-1588

Taylor WR, Chen E, Copenhagen DR (1995) Characterization of spontaneous excitatory synaptic currents in salamander retinal ganglion cells. J Physiol (Lond) 486:207-221.

Tomita S, Fukata M, Nicoll RA, Bredt DS (2004) Dynamic interaction of stargazin-like TARPs with cycling AMPA receptors at synapses. Science 303:1508-1511.

Turrigiano GG (2000) AMPA receptors unbound: membrane cycling and synaptic plasticity. Neuron 26:5-8.

Walters RJ, Kramer RH, Nawy S (1998) Regulation of cGMP-dependent current in On bipolar cells by calcium/calmodulin-dependent kinase. Vis Neurosci 15:257-261.

Xia J, Chung HJ, Wihler C, Huganir RL, Linden DJ (2000) Cerebellar longterm depression requires PKC-regulated interactions between GluR2/3 and PDZ domain-containing proteins. Neuron 28:499-510. 